\title{
A Multi-Criterion Analysis of Cross-Strait Co-Opetitive Strategy in the Crystalline Silicon Solar Cell Industry
}

\author{
Hsiao-Chi Chen ${ }^{1}$ and Chia-Han Yang ${ }^{2}$ \\ ${ }^{1}$ Department of Business Administration, Chung Yuan Christian University, 200 Chung Pei Road, Chungli 32023, Taiwan \\ ${ }^{2}$ Institute of Creative Industry Design, National Cheng Kung University, No. 1, University Road, Tainan 701, Taiwan \\ Correspondence should be addressed to Hsiao-Chi Chen; hc_chen@cycu.edu.tw
}

Received 3 July 2013; Revised 28 September 2013; Accepted 24 October 2013; Published 16 March 2014

Academic Editor: Jung-Fa Tsai

Copyright (c) 2014 H.-C. Chen and C.-H. Yang. This is an open access article distributed under the Creative Commons Attribution License, which permits unrestricted use, distribution, and reproduction in any medium, provided the original work is properly cited.

\begin{abstract}
The research adopts multi-criterion analysis to face cross-strait cooperative and competitive (co-opetitive) strategies problem in the crystalline silicon solar cell industry between Taiwan and China. The analysis framework is based on the national competitiveness. The Analytical Hierarchy Process (AHP) approach and TOPSIS analysis are applied to analyze firm-level data, gathered from the solar cell companies across the Taiwan Strait. For the Taiwanese firms, their relative national competitiveness lies in technology development, domestic market, international competition in related industries, and subsidy policy. For the Chinese firms, domestic market, procurement conditions, customization, intellectual resources, risk capital, and human quality are found to be their competitive advantages. Both China and Taiwan have entered into the emerging solar cell industry, with an aim to climb beyond the ladder of catch up. The results have shown that Taiwan and China can explore the possibility of forging strategic alliances by exploiting national competitiveness on the demand side. Above all, the paper has managed to spotlight demand conditions as the crucial factors for China and Taiwan to enhance their international competitiveness in the emerging solar cell industry.
\end{abstract}

\section{Introduction}

Growing global concern on the triple crisis of finance, environment, and development has given rise to extensive research and investment in renewable energy such as photovoltaic, solar thermal, wind power, hydropower, and fuel cell to replace fossil fuel as the primary energy source. Among the abovementioned energy sources, development on solar energy, particularly solar cells, has been regarded as the star of the future for its technological potentials and closer gap towards commercialization, which has in turn led to studies on competition and development related issues, with special focus on the technology level, cost-effectiveness, and other fundamental aspects [1]. A key to competition between various photovoltaic cell types is the energy conversion efficiency, which is largely determined by the manufacturing technology [2]. Solar cells are categorized into two main groups, namely, the wafer-type and thin film. The wafer-type manufactured through single crystalline or multicrystalline technology has captured the lion's market share of $95 \%$ in
2007, for its established advantages of lower manufacturing cost and higher efficiency over the thin-film counterpart which is based on a-Si, Cd-Te, and CIGS technologies and struggles with the remaining $5 \%$. Thus, the crystalline silicon solar cell industry has become the major battlefield for a number of industrial players in the global landscape.

Heightening concern has existed among governments around the globe that the national competitiveness will be crippled by the threat of fossil fuel depletion as development is evidently driven by increasing energy consumption and fossil fuel still serves as the primary energy source. This had led to relentless efforts by governments in many countries in search for sustainable alternative energy sources through both $\mathrm{R} \& \mathrm{D}$ and market stimulation policies, of which the solar cell industry is one of the major focus, as seen in Germany and Italy [3]. In light of mounting threat posed by major competitors from Japan, USA, and Europe to the Taiwan's industry, the Taiwanese government has stepped up its effort in formulating co-opetitive (cooperative and competitive) strategies in the cross-strait context. It is well established that 


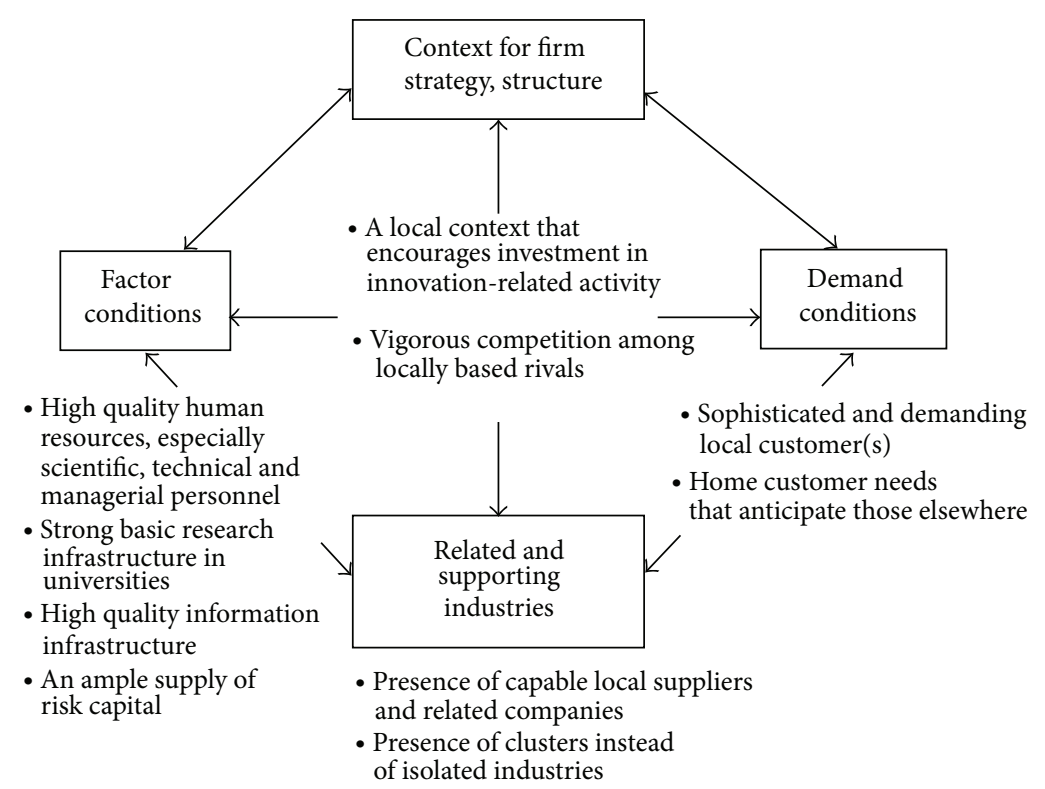

FIgURE 1: The innovation orientation of Diamond Model. Source: Furman et al. [7].

the developmental momentum of an emerging and hightechnology industry, such as the solar cell industry, may be influenced by the national competitiveness [4]. Therefore, it is crucial to take national competiveness into consideration when one is to formulate the competition strategy for the solar cell industry at national level and also analyze the strategy planning for crystalline silicon solar cell firms. Against the above backdrop, this paper adopts the national competitiveness perspective to examine the development and strategic option of the solar cell industry in both Taiwan and China while considering the policy influences across the Taiwan Strait.

In the global supply chain of the crystalline silicon solar cell industry, China and Taiwan are both strong players in the manufacturing of cell production and modules. Although competition and coordination relationships exist in the crystalline silicon solar cell industry between China and Taiwan, the Taiwanese firms have been trying to leverage advantages and market opportunities that can be offered by the wafer solar cell firms in China. This research therefore sets out to analyze the national competitiveness in the crystalline silicon solar cell industry in the cross-strait context, with an aim to examine appropriate co-opetitive strategies for the firms on both sides. Our analyses are shaped by an inquiry into the argument that new sources of national competitiveness are required for both China and Taiwan to promote emerging industries, such as the crystalline silicon solar cell industry.

This paper is structured as follows. Section 2 touches on Porter's Diamond Model of national competitiveness and its revised version, which together form the core of our theoretical framework. Section 3 discusses research methods employed by this research, namely, Analytic Hierarchy Process (AHP) and TOPSIS (Technique for Order Preference by Similarity to an Ideal Solution). Section 4 presents our empirical analyses on the cross-strait co-opetitive strategy in crystalline silicon solar cell industry and draws implications. This paper makes conclusions in Section 5.

\section{Theoretical Framework of National Competitiveness}

In the traditional trade theory, capital, labor, and natural resources are regarded as the major sources of national competitiveness [5]. Before Porter's Diamond Model [6] was introduced, there were no comprehensive system and concept to discuss national competitiveness. The Diamond Model is a cluster-based theory of national industrial competitive advantage that spotlights factor conditions, firm strategy, structure, and related and supporting industries, and demand conditions with exogenous variability of government and chances as the major sources of national competitiveness. For emphasizing national innovation capability, the Porter framework encapsulates the forces by identifying four key drives (see [7]; Figure 1). The first is the availability of high quality and specialized innovation inputs. A second determinant is the extent to which the local competitive context is intense and rewards successful innovators. A third determinant of cluster-level innovation is the nature of domestic demand for cluster producers and services. The final element in this framework is the availability, density, and interconnectedness of vertically and horizontally related industries. Overall, this framework suggests that the level of realized innovation in an economy depends upon the degree to which private $\mathrm{R} \& \mathrm{D}$ is fueled by innovation-based domestic competition.

However, the Diamond Model is criticized for the lack of incorporation of multinational activities and discussion of the impact of human variables and government. Consequently, the Double Diamond Model [8-11] is introduced as 
TABLE 1: Criteria of national competitiveness for this research.

\begin{tabular}{|c|c|c|}
\hline Dimensions & Criteria & References \\
\hline \multirow{6}{*}{ Factor conditions } & Quality of human resources & \multirow{6}{*}[6,7,19,36]{} \\
\hline & Cost of human resources & \\
\hline & Natural resources & \\
\hline & Intellectual resources & \\
\hline & Risk capital & \\
\hline & Infrastructure & \\
\hline \multirow{4}{*}{ Demand conditions } & Market demand & \multirow{4}{*}[6,7,19,20,36]{} \\
\hline & Domestic/overseas procurement condition & \\
\hline & Government procurement & \\
\hline & Customization & \\
\hline \multirow{3}{*}{ Related and supporting industries } & The degree of industrial cluster & \multirow{3}{*}[6,21]{} \\
\hline & The degree of vertical integration & \\
\hline & International competition in related industries & \\
\hline \multirow{6}{*}{ Competitive structure } & Number of firms & \multirow{6}{*}[6,21-23,37]{} \\
\hline & Scale of firm & \\
\hline & Quality of firm & \\
\hline & The level of innovation & \\
\hline & Strategic activities of firms & \\
\hline & Industrial culture & \\
\hline \multirow{6}{*}{ Government (law) } & Industry and investment policy & \multirow{6}{*}[6,19,24,25,38,39]{} \\
\hline & Education policy & \\
\hline & Economic policy & \\
\hline & Regulatory policy & \\
\hline & Subsidy policy & \\
\hline & Monetary policy & \\
\hline \multirow{4}{*}{ Opportunities } & Change of international financial market & \multirow{4}{*}[6,26,27,38]{} \\
\hline & Change of international political environment & \\
\hline & Technology invention & \\
\hline & Energy shortage & \\
\hline
\end{tabular}

Chen and Yang, 2011 [40]

an extension to Porter's single Diamond Model by incorporating international competitiveness into the single Diamond Model. The Nine-Factor Model [12, 13] which addressed different view of Porter's Diamond Model is another extension to Porter's original model with four additional human variables of workers, politicians and bureaucrats, and professionals being added in the model. In short, Cho et al. [14] formulate the Dual Double Diamond Model, which considers both physical and human factors in both domestic and international contexts to analyze national competiveness.

In the national competitiveness studies researchers often develop new evaluation model through adjustment of Porter's Diamond Model. However, the variables of Porter's single Diamond Model are still useful and often adopted for national competitiveness analyses [15-18]. In this research, the research framework is based on Porter's Diamond Model and other past studies on national competitiveness [7, 1927]. The criteria of national competitiveness are adopted from Porter's national competitiveness approach, Double Diamond Model, and Nine-Factor Model as shown in Table 1.

\section{Research Methods}

This research is based on a questionnaire survey addressed to the firms in the crystalline silicon solar cell industry in Taiwan and China. For the Taiwanese firms, 25 samples are collected out of the 78 crystalline silicon solar cell firms with a return rate of $32 \%$. 19 samples are obtained from 67 crystalline silicon solar cell firms in China and return rate is $28 \%$. Although the return rate of $30.3 \%$ seems insufficient to represent the entire industry, the samples are collected from the representative firms in the crystalline silicon solar cell industry and therefore should be sufficient to represent the competitive situation of the whole industry.

Decision making is the process of selecting a possible course of action from all of the available alternatives. However, multiple criteria would influence the decision making. In order to capture the decision making at issue in the wafer base solar cell industry, Analytic Hierarchy Process (AHP) and TOPSIS (Technique for Order Preference by Similarity to an Ideal Solution) are applied to find a compromising 
solution in the cross-strait co-opetitive strategies. AHP is adopted to analyze the critical national competitiveness between Taiwan and China, for its advantage in providing weighing and prioritization which assists the strategy of decision making process for managers of the crystalline silicon solar cell firms. On the other hand, TOPSIS is used to evaluate preferred co-opetitive strategy for the cross-strait crystalline silicon solar cell firms.

AHP is a decision aiding method developed by Saaty [28-30], Saaty and Kearns [31]. It is aimed at quantifying relative priorities for a given set of alternatives on a ratio scale, based on the judgment of the decision maker, stressing the importance of the intuitive judgments of a decision maker as well as the consistency of the comparison of alternatives in the decision making process [28]. Since judgments of a decision maker are based on knowledge and experience, to make decisions accordingly, the AHP approach agrees well with the behavior of a decision maker. Saaty [28] developed the following steps for applying the AHP.

(1) Define the problem and determine its goal.

(2) Structure the hierarchy from the top (the objectives from a decision maker's viewpoint) through the intermediate levels (criteria on which subsequent levels depend) to the lowest level which usually contains the list of alternatives.

(3) Construct a set of pairwise comparison matrices (size $n \times n)$ for each of the lower levels with one matrix for each element in the level immediately above by using the relative scale measurement. The pairwise comparisons are done in terms of which element dominates the other.

(4) There are $n(n-1) /$ judgments required in developing the set of matrices in step (3). Reciprocals are automatically assigned in each pairwise comparison.

(5) Hierarchical synthesis is used to weigh the eigenvectors by the weights of the criteria and the sum is taken over all weighed eigenvector entries corresponding to those in the next lower level of the hierarchy.

(6) Having made all the pairwise comparisons, the consistency is determined by using the eigenvalue, $\lambda_{\text {max }}$, to calculate the consistency index, $\mathrm{CI}$ as follows:

$$
\mathrm{CI}=\frac{\lambda_{\max }-n}{n-1},
$$

where $n$ is the matrix size. Judgment consistency can be checked by taking the consistency ratio (CR) of CI with the appropriate value. The CR is acceptable, if it does not exceed 0.10 . If it is more, the judgment matrix is inconsistent. To obtain a consistent matrix, judgments should be reviewed and improved.

(7) Steps (3-6) are performed for all levels in the hierarchy.

Global criterion method, goal programming, fuzzy programming, and interactive approaches all need initial reference points in order to obtain (a) compromise solution(s)
[32]. To obtain a compromising solution, the distance family with the ideal solution is reference point used by global criteria method. The TOPSIS approach could solve the auxiliary problem. The TOPSIS method is presented in Chen and Hwang [33], with reference to Hwang and Yoon [34]. The basic principle is that the chosen alternative should have the shortest distance from the ideal solution and the farthest distance from the negative ideal solution. There are such methods to use linear normalization (like VIKOR method), while the TOPSIS method uses vector normalization. Additionally, the normalized values by vector normalization in the TOPSIS method may depend on the evaluation unit [35]. Then, TOPSIS have two "reference" points for ideal solution, but it does not consider the relative importance of the distances from these points.

The idea of TOPSIS can be expressed in a series of steps.

(1) Calculate the normalized decision matrix. The normalized value $\gamma_{i j}$ is calculated as

$$
\gamma_{i j}=\frac{f_{i j}}{\sqrt{\sum_{j=1}^{J} f_{i j}^{2}}}, \quad j=1, \ldots, J ; i=1, \ldots, n .
$$

(2) Develop a set of importance weights $w_{i}$, for each of the criteria. The weighted normalized value $v_{i j}$ is calculated as

$$
v_{i j}=w_{i} r_{i j}, \quad j=1, \ldots, J ; i=1, \ldots, n,
$$

where $w_{i}$ is the weight of the $i$ th attribute or criterion and $\sum_{i=1}^{n} w_{i}=1$.

(3) Identify the ideal (extreme performance on each criterion) and nadir (reverse extreme performance on each criterion) solution:

$$
\begin{aligned}
A^{*} & =\left\{v_{1}^{*}, \ldots, v_{n}^{*}\right\} \\
& =\left\{\left(\max v_{i j} \mid i \in I^{\prime}\right),\right\}\left(\min v_{i j} \mid i \in I^{\prime \prime}\right), \\
A^{-} & =\left\{v_{1}^{-}, \ldots, v_{n}^{-}\right\} \\
& =\left\{\left(\min v_{i j} \mid i \in I^{\prime}\right),\right\}\left(\max v_{i j} \mid i \in I^{\prime \prime}\right),
\end{aligned}
$$

where $I^{\prime}$ is associated with benefit criteria and $I^{\prime \prime}$ is associated with cost criteria.

(4) Develop a distance measure over each criterion to both ideal $\left(D^{*}\right)$ and nadir $\left(D^{-}\right)$. The separation of each alternative from the ideal solution is given as

$$
D_{j}^{*}=\sqrt{\sum_{i=1}^{n}\left(v_{i j}-v_{i}^{*}\right)^{2}}, \quad j=1, \ldots, J .
$$

Similarly, the separation from the negative ideal solution is given as

$$
D_{j}^{-}=\sqrt{\sum_{i=1}^{n}\left(v_{i j}-v_{i}^{-}\right)^{2}}, \quad j=1, \ldots, J .
$$


TABLE 2: The competitive advantage analysis of nations in the crystalline silicon solar cell industry.

\begin{tabular}{lccc}
\hline & Technology & Manufacturing & System and marketing \\
\hline American & $\bullet$ & $\odot$ & $\bullet$ \\
Germany & $\bullet$ & $\bullet$ & $\bullet$ \\
Japan & $\bullet$ & $\odot$ & $\bullet$ \\
Taiwan & $\bigcirc$ & $\bullet$ & $\bigcirc$ \\
China & $\bigcirc$ & $\bullet$ & $\bigcirc$ \\
\hline
\end{tabular}

-: absolute advantage; $\odot$ : comparative advantage; $\bigcirc$ : having resource.

Resource: processed from second sources organized and experts' interview.

TABLE 3: The comparison of national competitiveness in the crystalline silicon solar cell industry for America, Germany, Japan, China, and Taiwan.

\begin{tabular}{|c|c|c|c|c|c|c|}
\hline Dimensions & Criteria & America & Germany & Japan & China & Taiwan \\
\hline \multirow{5}{*}{ Factor conditions } & Quality of human resources & $\bullet$ & $\bullet$ & 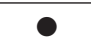 & $\bigcirc$ & $\odot$ \\
\hline & Cost of human resources & $x$ & $x$ & $x$ & $\bullet$ & $\odot$ \\
\hline & Intellectual resources & $\bullet$ & • & $\bullet$ & $\bigcirc$ & $\odot$ \\
\hline & Risk capital & $\bullet$ & $\bullet$ & $\bullet$ & $\odot$ & $\odot$ \\
\hline & Dimensional evaluation & $\bullet$ & $\bullet$ & $\bullet$ & $\odot$ & $\odot$ \\
\hline \multirow{4}{*}{ Demand conditions } & Market demand & $\bullet$ & $\bullet$ & $\bullet$ & $\odot$ & $\bigcirc$ \\
\hline & Domestic/overseas procurement condition & $\bullet$ & $\bullet$ & - & $\bigcirc$ & $\odot$ \\
\hline & Government procurement & $\bullet$ & $\bullet$ & $\bullet$ & $\bigcirc$ & $\bigcirc$ \\
\hline & Dimensional evaluation & ○ & ○ & $\bullet$ & $\bigcirc$ & $\bigcirc$ \\
\hline \multirow{4}{*}{ Related and supporting industries } & The degree of industrial cluster & $\odot$ & $\bullet$ & $\bullet$ & $\odot$ & $\odot$ \\
\hline & The degree of vertical integration & $\odot$ & • & $\bullet$ & $\odot$ & $\bigcirc$ \\
\hline & International competition in related industries & $\bullet$ & $\bullet$ & $\bullet$ & $\odot$ & $\odot$ \\
\hline & Dimensional evaluation & $\odot$ & ○ & ○ & $\odot$ & $\odot$ \\
\hline \multirow{4}{*}{ Competitive structure } & Number of firms & $\bigcirc$ & $\odot$ & $\odot$ & $\bullet$ & $\odot$ \\
\hline & Scale of firm & $\odot$ & $\bullet$ & $\bullet$ & $\bullet$ & $\odot$ \\
\hline & Strategic activities of firms & $\odot$ & $\bullet$ & $\bullet$ & $\odot$ & $\bigcirc$ \\
\hline & Dimensional evaluation & $\odot$ & $\bullet$ & $\bullet$ & $\bullet$ & $\odot$ \\
\hline \multirow{7}{*}{ Government (law) } & Education policy & $\bullet$ & $\bullet$ & $\bullet$ & $\bigcirc$ & $\odot$ \\
\hline & Economic policy & $\odot$ & $\bullet$ & $\bullet$ & $\odot$ & $\odot$ \\
\hline & Regulatory policy & $\odot$ & • & $\bullet$ & $\mathrm{O}$ & $\odot$ \\
\hline & Industry and investment policy & $\bullet$ & $\bullet$ & $\bullet$ & $\odot$ & $\bigcirc$ \\
\hline & Subsidy policy & • & $\bullet$ & $\odot$ & $\bigcirc$ & $\bigcirc$ \\
\hline & Monetary policy & $\bullet$ & $\bullet$ & $\bullet$ & $\odot$ & $\odot$ \\
\hline & Dimensional evaluation & $\bullet$ & - & $\bullet$ & $\odot$ & $\odot$ \\
\hline \multicolumn{2}{|c|}{ Overall evaluation } & $\bullet$ & ? & $\bullet$ & $\odot$ & $\odot$ \\
\hline
\end{tabular}

๑: absolute advantage; $\odot$ : comparative advantage; $\bigcirc$ : having resource; $x$ : no advantage.

Resource: processed from second sources organized and experts' interview.

(5) For each alternative, determine a ration $R_{j}^{*}$ equal to the distance to the nadir divided by the sum of the distance to the nadir and the distance to the ideal:

$$
R_{j}^{*}=\frac{D_{j}^{-}}{\left(D_{j}^{*}-D_{j}^{-}\right)}, \quad j=1, \ldots, J .
$$

(6) Rank the preference order.

\section{The Cross-Strait Co-Opetitive Strategy in Crystalline Silicon Solar Cell Industry}

4.1. The National Competitiveness between Taiwan and China. Interviews with the industrial experts from the solar cell industry are conducted to examine the cross-strait national competitiveness as shown in Tables 2 and 3. The competitiveness criteria to evaluate country comparison in Table 3 are based on secondary data and expert interviews.

In order to evaluate the national competitiveness and advantage in America, Germany, Japan, China, and Taiwan, 
this research began by compiling secondary industrial data from industry reports and news [41-44] to formulate a draft national competitiveness and advantage table. Second, opinions and views from executive managers in the flagship companies and research institution, including Motech, Sun Q Solar, Sunrise Global Solar Energy, Neo Solar Power, Suntech Power Holdings, and Photovoltaics Technology Center of ITRI (Industrial Technology Research Institute), are used to verify the data.

America, Germany, Japan, China, and Taiwan are the main nations developing the crystalline silicon solar cell industry. In the national competitiveness analysis shown in Table 2, relative advantages in technology, manufacturing, system, and marketing status are used to demonstrate the competitive advantage of nations in the industrial supply chain. In general, America, Germany, and Japan have sufficient resource and conditions to support the industry's development in technology, manufacturing, system, and marketing. The crystalline silicon solar cell firms in these nations are very likely to adopt the vertical integration model. In contrast, both Taiwan and China have absolute advantage in manufacturing; hence their crystalline silicon solar cell firms are engaged in intense competition across the Taiwan Strait.

The national competitive advantage is further analyzed for America, Germany, Japan, China, and Taiwan, as shown in Table 3. Factor conditions, demand conditions, related and supporting industries, competitive structure, and government (law) are strong advantages for America, Germany, and Japan, making vertical integration as the important strategy for the crystalline silicon solar cell firms in these countries. However, Taiwan only has comparative advantages for factor conditions, related and supporting industries, and government (law). China has more comparative advantages than Taiwan because of its earlier development in the solar cell area. These conditions have prompted the crystalline silicon solar cell firms in Taiwan and China to focus mainly on "manufacturing"; see Table 2. Based on the result of Table 2, it can be argued that Taiwan and China are in the same position in the crystalline silicon solar cell supply chain to compete mainly in the manufacturing field. Table 3 goes further to reveal that there are some coordination opportunities between China and Taiwan in areas such as quality of human resources, market demand, and so on.

A closer look at Table 3 suggests a key research issue for this study: how the Taiwanese firms are to face or come to terms with their Chinese counterparts, given China's stronger national competitiveness? The comprehensive decision making of the crystalline silicon solar cell competition strategy is a complex process and multiconditions should be considered. Therefore, this research focuses on the competition and coordination strategy in the crystalline silicon solar cell industry between Taiwan and China by first exploring the critical criteria of national competitiveness which may influence the co-opetitive strategy planning.

This paper used the national competiveness criteria, as shown in Table 1, and took AHP evaluation to unveil the critical national competitiveness from the firms' viewpoint. The comparison analysis of cross-strait national competitiveness is shown in Table 4.
Our results suggest that "Demand Conditions," "Government," and "Chances" are critical dimensions for Taiwan to develop the crystalline silicon solar cell industry. Several key national competitiveness, such as domestic market, the environment change of international finance, subsidy policy, and energy shortage, can fuel the Taiwanese firms to become competitive in the industry. Closer examination of the national competitiveness for Taiwan suggests that the government can function as an external driving force to influence and support the crystalline silicon solar cell industry.

For China to develop the crystalline silicon solar cell industry, "Demand Conditions" and "Factor conditions" are found to be key competitive dimensions. Domestic market, procurement conditions, customization, intellectual resources, risk capital, and human quality turn out to be important national competitiveness for the industry's development. In particular, Demand condition is the most critical issue in China. The ambitious effort "to build the solar city" in China is the crucial policy for the development of the local industry and energy is one of the main projects in China's 12th 5-year plan.

In short, market demand, domestic/overseas procurement condition, risk capital, and government procurement are focal points in the competitiveness of Taiwan and China. Indeed, the crystalline silicon solar cell industry is in the emerging stage and the government can play a key role in subsidizing R\&D and cultivating various market demands. Hence, government's supporting activities may influence the investment incentive of the firms in the industry.

With comparing cross-strait national competitiveness, this research identifies 9 criteria which are crucial to the development of the crystalline silicon solar cell industry for Taiwan and China, as shown in Table 5. Comparing the national competitiveness between Taiwan and China, there are some notable findings, as follows: (1) Taiwan has stronger subsidy policy but higher risk of energy shortage in comparison with China; (2) international competition in related industries and the level of innovation for Taiwan have much to do with accumulated strengths from the ICT industry; (3) contrarily, intellectual assets, the degree of customization, quality of human resource, and natural assets are advantages for China to develop the industry. In addition, niche market and key resources provider seem to be strategic focuses for the firms in China.

By integrating information gathered from Tables 3 and 5 , one can shed light to strategies in the cross-strait context. "International competition in related industries" and "the level of innovation" seem to be Taiwanese advantages to coordinate with China's crystalline silicon solar cell industry. However, there are different views, regarding "quality of human resources" and "intellectual resources" in Taiwan, from the qualitative and quantitative analyses. Information gathered expert interviews tend to suggest that these factors are still Taiwanese advantages, compared to China, while "customization," "natural resources," and "infrastructure" are China's competitiveness for the Taiwanese side to take advantage of. These findings form important base for us to discuss optimal co-opetitive strategy between Taiwan and China, to be discussed below. 
TABLE 4: Comparison of cross-strait national competitiveness in the crystalline silicon solar cell industry.

\begin{tabular}{|c|c|c|c|c|c|}
\hline \multicolumn{3}{|c|}{ Taiwan } & \multicolumn{3}{|l|}{ China } \\
\hline Priority & Weight & Criteria & Criteria & Weight & Priority \\
\hline 1st & 0.1502 & Market demand & Market demand & 0.1391 & 1st \\
\hline 2nd & 0.0927 & $\begin{array}{l}\text { Change of international financial } \\
\text { market }\end{array}$ & $\begin{array}{l}\text { Domestic/overseas procurement } \\
\text { condition }\end{array}$ & 0.0887 & 2nd \\
\hline $3 \mathrm{rd}$ & 0.0937 & Subsidy policy & Customization & 0.0691 & $3 \mathrm{rd}$ \\
\hline 4 th & 0.0651 & Energy shortage & Risk capital & 0.0645 & 4 th \\
\hline 5 th & 0.0532 & $\begin{array}{l}\text { Domestic/overseas procurement } \\
\text { condition }\end{array}$ & Intellectual resources & 0.0618 & 5 th \\
\hline 6 th & 0.0505 & $\begin{array}{l}\text { International competition in related } \\
\text { industries }\end{array}$ & Quality of human resources & 0.0541 & 6 th \\
\hline 7 th & 0.0417 & Industry and investment policy & Natural resources & 0.0482 & 7th \\
\hline 8 th & 0.0383 & The level of innovation & $\begin{array}{l}\text { Change of international financial } \\
\text { market }\end{array}$ & 0.0435 & 8 th \\
\hline 9th & 0.0372 & Risk capital & The degree of vertical integration & 0.0427 & 9th \\
\hline 10th & 0.0369 & Economic policy & Government procurement & 0.0395 & 10th \\
\hline 11th & 0.0358 & Strategic activities of firms & Quality of firm & 0.0378 & 11 th \\
\hline 12th & 0.0320 & Government procurement & Industry and investment policy & 0.0351 & 12 th \\
\hline 13th & 0.0313 & $\begin{array}{l}\text { Change of international political } \\
\text { environment }\end{array}$ & Infrastructure & 0.0342 & 13th \\
\hline 14 th & 0.0291 & The degree of vertical integration & $\begin{array}{l}\text { International competition in related } \\
\text { industries }\end{array}$ & 0.0339 & 14 th \\
\hline 15th & 0.0285 & Quality of firm & Energy shortage & 0.0306 & 15 th \\
\hline 16th & 0.0252 & Technology invention & $\begin{array}{l}\text { Change of international political } \\
\text { environment }\end{array}$ & 0.0294 & 16 th \\
\hline 17th & 0.0241 & Intellectual resources & Economic policy & 0.0287 & 17 th \\
\hline 18th & 0.0235 & Quality of human resources & The level of innovation & 0.0231 & 18 th \\
\hline 19th & 0.0227 & Monetary policy & Technology invention & 0.0200 & 19th \\
\hline 20th & 0.0176 & Customization & The degree of industrial cluster & 0.0192 & 20th \\
\hline 21th & 0.0169 & The degree of industrial cluster & Strategic activities of firms & 0.0188 & 21th \\
\hline 22th & 0.0166 & Education policy & Cost of human resources & 0.0165 & 22th \\
\hline 23th & 0.0163 & Scale of firm & Monetary policy & 0.0121 & 23th \\
\hline 24th & 0.0151 & Regulatory policy & Education policy & 0.0102 & 24th \\
\hline 25 th & 0.0106 & Cost of human resources & Regulatory policy & 0.0085 & 25 th \\
\hline 26th & 0.0106 & Infrastructure & Subsidy policy & 0.0075 & 26th \\
\hline 27 th & 0.0065 & Natural resources & Scale of firm & 0.0072 & 27 th \\
\hline 28th & 0.0032 & Number of firm & Number of firm & 0.0053 & 28 th \\
\hline
\end{tabular}

TABLE 5: Comparing cross-strait difference of national competitiveness in the crystalline silicon solar cell industry.

\begin{tabular}{|c|c|c|c|c|}
\hline \multicolumn{2}{|c|}{ Taiwan } & \multirow{2}{*}{ Criteria } & \multicolumn{2}{|c|}{ China } \\
\hline Priority & Weight & & Weight & Priority \\
\hline 3 rd & 0.0937 & Subsidy policy & 0.0075 & 26 th \\
\hline 4 th & 0.0651 & Energy shortage & 0.0306 & 15 th \\
\hline 6 th & 0.0505 & International competition in related industries & 0.0339 & 14 th \\
\hline 8th & 0.0383 & The level of innovation & 0.0231 & 18th \\
\hline 17 th & 0.0241 & Intellectual resources & 0.0618 & 5 th \\
\hline 20th & 0.0176 & Customization & 0.0691 & $3 \mathrm{rd}$ \\
\hline 18th & 0.0235 & Quality of human resource & 0.0541 & 6th \\
\hline 27 th & 0.0065 & Natural resources & 0.0482 & 7 th \\
\hline
\end{tabular}


Given the critical factors of national competitiveness between Taiwan and China, discussed above, the size difference in domestic markets seems to have a strong influence on the firms' vision and the way of developing the crystalline silicon solar cell industry. According to the results of our analyses on critical criteria for national competitiveness, the Taiwanese firms tend to consider the market dimensions as well as such factors as change of international financial market, subsidy policy, energy shortage, and so forth, as the most influential criteria for market stimulation. In addition, the Chinese firms tend to give high priority to the factors that can influence the global competition and strategic development, such as customization, intellectual resources, risk capital, quality of human resources, and so on. While previous studies on the development of emerging industries have paid particular attention to fierce competition in research $[6,45]$, technology leadership, and infrastructure, this paper has spotlighted demand conditions as the most important factor of competitiveness for both Taiwan and China to develop an emerging industry such as the crystalline silicon solar cell industry.

Our analyses suggest two strategic approaches for Taiwan and China to engage with global industrial evolution in the emerging crystalline silicon solar cell industry. An optimist strategy for China involves horizontal development and leveraging the national competitiveness of factor conditions and infrastructure, while a pragmatist strategy for Taiwan requires further government policy support to open up "opportunities," for example, by cultivating the domestic market and/or helping outreach larger external market, such as the Chinese market [46]. On balance, the size difference in domestic markets between Taiwan and China matters a great deal for the competitiveness and strategic options at the firm level.

4.2. The Cross-Strait Co-Opetitive Strategy. Although the Taiwanese firms are still falling behind Japan, US, and Europe in the crystalline silicon solar cell industry, they do possess great potential for Taiwan's well-established production capacities and capabilities in the semiconductor, flat panel display (FPD), and conventional PV solar cell industries, which are highly related to the emergent industry. How could the Taiwanese crystalline silicon solar cell firms leverage the advantages and national competiveness to strengthen their position and competitiveness? Obviously, firms within a manufacturing/innovation network can integrate and collaborate with each other in order to develop new strategies, capacities, and capabilities to withstand global competition.

The competiveness analyses above not only present the strategic issues for the firms but also reveal the complementary assets and cooperation mechanism between Taiwan and China. Further investigation is made in this research by applying the TOPSIS method to analyze co-opetitive strategy in the crystalline silicon solar cell industry between Taiwan and China. Our analyses on the preferred co-opetitive strategy for the firms on both sides of the Taiwan Strait are based on national competitiveness as shown in Table 6. In particular, "Strategic alliance" as a strategic option is ranked high (second) by both the Taiwanese and Chinese
TABLE 6: The priority of cross-strait co-opetitive strategy in the crystalline silicon solar cell industry.

\begin{tabular}{lcc}
\hline Strategy & \multicolumn{2}{c}{ Priority } \\
\hline Competition strategy & Taiwan & China \\
Low-cost leadership & 1 st & $3 \mathrm{rd}$ \\
Differentiated products & $3 \mathrm{rd}$ & 5 th \\
Focus & 4 th & 1 st \\
Collaborative strategy & & \\
Merger and acquisition & 5 th & 6 th \\
Strategic alliance & $2 \mathrm{nd}$ & $2 \mathrm{nd}$ \\
Joint ventures & 6 th & 7 th \\
Technology licensing & 7 th & 4 th \\
\hline
\end{tabular}

firms. The results suggest that the firms in Taiwan first intend to strengthen low-cost leadership as competitive strategy against competition from the Chinese firms. In addition, some of the Taiwanese firms go further to pursue an outbound strategy, which makes Market demand, Change of international financial market, and Domestic/overseas Procurement conditions (see Table 4) the critical factors of competitiveness.

In other words, although cost advantage remains essential to the Taiwanese players, whose operations tend to focus mainly on the manufacturing of cell production and modules, they can take advantage of China's sheer size market by adopting a collaborative strategy with the Chinese players, particularly in the form of strategic alliances. This strategy is indeed being facilitated by active efforts made by the Taiwanese government to promote cross-strait industrial collaboration. In addition, the Taiwanese firms can leverage Taiwan's accumulated strengths in "International competition in related industries" and "The level of innovation" (see Table 4) to engage with the Chinese players in a cooperative manner, given the fact that the stability of material supply is a critical competition factor in the solar cell industry and quality material (e.g., Wafer) is the key issue to attract collaboration with the Chinese firms.

On the other hand, the Chinese firms in the industry tend to adopt a focus strategy of market orientation as their first priority. Table 4 shows that market demand and domestic/overseas procurement condition are ranked high as major national competitiveness for the Chinese firms. In fact, the development of emerging industries, as the solar cell industry in China nowadays entails a coevolution process of social and market factors in shaping Chinese innovations, highlighting the significance of domestic demands in the Chinese industrial development. It is true that the Chinese players can enjoy cost advantage for manufacturing by benefitting from national competitiveness in natural resources, infrastructure, and cost of human resources. It is equally true that the Chinese industrial players have increasingly looked to the domestic market demand as the source of innovation and industrial competitiveness, when it comes to the development of emerging industries. Of note is the fact that the Chinese firms have shown a strong appreciation to 
"strategic alliance," with a second high ranking of strategic option. The strategic fit between the Taiwanese and Chinese sides regarding "Strategic alliance" can be facilitated by the differences in national competitiveness that each side possesses, discussed above. On balance, apart from the lowcost leadership strategy, "Strategic alliance" is found to be a feasible solution between Taiwan and China.

By implication, a substantial body of the existing literature on cross-strait economic relations tends to focus on the policy differences [47], economic issues [48, 49], or the role of the both sides in the global production/innovation networks [50], but this research into the development of emerging industry in the cross-strait environment suggests a broader context than what has been discussed. Specifically speaking, market demand has become an essential and integral part of industrial development and innovation for both China and Taiwan, when it comes to emerging industries, as the solar cell industry. In developing a few emerging industries, both China and Taiwan have approached the stage of just few steps behind the advanced countries or even on the equal footing as their international counterparts. As a result, market demand can no longer be subject to benign neglect for the formulation of appropriate industrial policy in China and Taiwan. In the cross-strait context, there have existed goodwill and measures from both sides to promote cross-strait industrial collaboration. Therefore, cross-strait co-opetitive strategies for a few emerging industries have come to the focal stage for policy analyses and policy design.

This research adopts the national competitiveness approach to examine important criteria for the firms from both sides to form cross-strait relation and strategy in the emerging solar cell industry. From the theoretical perspective, this research first revised Porter's Diamond Model, with reference to the broader Double Diamond Model and Nine-Factor Model, and then made intensive analyses on the critical factors of national competitiveness to propose the cross-strait co-opetitive strategy.

Additionally, the research makes interesting analyses on the upgrading process of global competition for the emerging solar cell industry in both Taiwan and China. Generally speaking, while leading international players, like Germany, Japan, and the USA, has established across-the-board strengths along the value chain in the industry, both Taiwan and China remain competitive mainly in the manufacturing of cell production and modules, which looks not so different from what they have done well in the course of industrialization. However, our results have shown that Taiwan and China can explore the possibility of forging strategic alliances by exploiting national competitiveness on the demand side.

\section{Conclusions}

Both China and Taiwan have entered into the emerging solar cell industry, with an aim to climb beyond the ladder of catch-up. Both of them are nowadays strong manufacturing players in the crystalline silicon solar cell supply chain but may possess different national competitiveness to explore for upgrading their competitiveness in the international race.
For the Taiwanese firms, their relative national competitiveness lie in technology development, domestic market, international competition in related industries, and subsidy policy. For the Chinese firms, domestic market, procurement conditions, customization, intellectual resources, risk capital, and human quality are found to be their competitive advantages. To enhance their international competitiveness, both the Taiwanese and Chinese industrial players tend to highly appreciate a few factors of strengthening competitiveness in market demand, domestic/overseas procurement condition, risk capital, and government procurement. This paper has therefore managed to spotlight demand conditions as the crucial factors for China and Taiwan to enhance their international competitiveness in the emerging solar cell industry. Apart from that, some notable differences in competitiveness factors between Taiwan and China are largely attributable to the size difference in domestic markets, which in turn has influenced the constituent firms' vision and their way of developing the crystalline silicon solar cell industry.

With particular regard to China, while Chinese economic and industrial development used to be associated mainly with foreign direct investment, technology transfer, and participation in the global production/innovation network, market demand has become an essential and integral part of industrial development and innovation for China, when it comes to emerging industries, as the solar cell industry. This is particularly true to the case where China champions indigenous innovation in the emerging sectors. Thanks to this new development, the Taiwanese firms in the solar cell industry have opted to engage with the Chinese players in a collaborative manner in order to take advantage of the market potential in the Chinese market.

As a result, market demand can no longer be subject to benign neglect for the formulation of appropriate industrial policy in China and Taiwan. The results of our analyses on national competitiveness for China and Taiwan have indeed revealed that the criteria of international and domestic demand, international and domestic procurement, capital resource, and government procurement are important factors to the cross-strait solar cell development. In the cross-strait context, there have existed goodwill and measures from both sides to promote cross-strait industrial collaboration, especially in a few emerging industries. With this intensive case study on cross-strait co-opetitive strategy in the crystalline silicon solar cell industry, the paper may help shed new light to the development of emerging industries in both China and Taiwan.

\section{Conflict of Interests}

The authors declare that there is no conflict of interests regarding the publication of this paper.

\section{References}

[1] T. D. Nielsen, C. Cruickshank, S. Foged, J. Thorsen, and F. C. Krebs, "Business, market and intellectual property analysis of polymer solar cells," Solar Energy Materials and Solar Cells, vol. 94, no. 10, pp. 1553-1571, 2010. 
[2] A. H. I. Lee, H. H. Chen, and H.-Y. Kang, "A model to analyze strategic products for photovoltaic silicon thin-film solar cell power industry," Renewable and Sustainable Energy Reviews, vol. 15, no. 2, pp. 1271-1283, 2011.

[3] F. Dinçer, "The analysis on photovoltaic electricity generation status, potential and policies of the leading countries in solar energy," Renewable and Sustainable Energy Reviews, vol. 15, no. 1, pp. 713-720, 2011.

[4] R. Whitley, "Developing innovative competences: the role of institutional frameworks," Industrial and Corporate Change, vol. 11, no. 3, pp. 497-528, 2002.

[5] A. Smith, An Inquiry into the Nature and Causes of the Wealth of Nations, W. E. Charles, Ed., The Harvard Classics, P.F. Collier \& Son Corporation, New York, NY, USA, 1937.

[6] M. E. Porter, The Competitive Advantage of Nations, Free Press, New York, NY, USA, 1990.

[7] J. L. Furman, M. E. Porter, and S. Stern, "The determinants of national innovative capacity," Research Policy, vol. 31, no. 6, pp. 899-933, 2002.

[8] A. M. Rugman, "Diamond in the rough," Business Quality, vol. 55, no. 3, pp. 61-64, 1991.

[9] A. M. Rugman and J. R. D’Cruz, “The double diamond model of international competitiveness: the Canadian experience," Management International Review, vol. 33, pp. 17-39, 1993.

[10] H. C. Moon, A. M. Rugman, and A. Verbeke, "A generalized double diamond approach to the global competitiveness of Korea and Singapore," International Business Review, vol. 7, no. 2, pp. 135-150, 1998.

[11] J. H. Dunning, "The role of foreign direct investment in upgrading China's competitiveness," Journal of International Business Economic, vol. 4, no. 1, pp. 1-13, 2003.

[12] D. S. Cho, "A dynamic approach to international competitiveness: the case of Korea," Journal of Far Eastern Business, vol. 1, no. 1, pp. 17-36, 1994.

[13] D. S. Cho and H. C. Moon, From Adam Smith to Michael Porter, World Scientific, Singapore, 2000.

[14] D. S. Cho, H. C. Moon, and M. Y. Kim, "Competitive strategy to enhance national competitiveness," in Proceedings of the Annual Meeting of the Academy of International Business, Beijing, China, June 2006.

[15] T. Padmore and H. Gibson, "Modelling systems of innovation: II. A framework for industrial cluster analysis in regions," Research Policy, vol. 26, no. 6, pp. 625-641, 1998.

[16] M. E. Porter, "Building the microeconomic foundations of prosperity: findings from the microeconomic competitiveness index," in The World Economic Forum's Global Competitiveness Report 2002-2003, pp. 23-45, Oxford University Press, Oxford, UK, 2003.

[17] H.-C. Lai and J. Z. Shyu, "A comparison of innovation capacity at science parks across the Taiwan Strait: the case of Zhangjiang High-Tech Park and Hsinchu Science-based Industrial Park," Technovation, vol. 25, no. 7, pp. 805-813, 2005.

[18] C. N. Maxoulis, H. P. Charalampous, and S. A. Kalogirou, "Cyprus solar water heating cluster: a missed opportunity?" Energy Policy, vol. 35, no. 6, pp. 3302-3315, 2007.

[19] P. Kotler, S. Jatusripitak, and S. Maesincee, The Marketing of Nations: A Strategic Approach to Building National Wealth, Free Press, New York, NY, USA, 1997.

[20] C. Edquist and L. Hommen, "Systems of innovation: theory and policy for the demand side," Technology in Society, vol. 21, no. 1, pp. 63-79, 1999.
[21] D. Mowery and R. Nelson, Sources of Industrial LeadershipStudies of Seven Industries, Cambridge University Press, Cambridge, Mass, USA, 1999.

[22] A. D. Chandler Jr., Scale and Scope: The Dynamics of Industrial Capitalism, Harvard University Press, Cambridge, Mass, USA, 1990.

[23] A. D. Chandler Jr., Shaping the Industrial Century: The Remarkable Story of the Modern Chemical and Pharmaceutical Industries, Harvard University Press, Cambridge, Mass, USA, 2005.

[24] M. Howlett and M. Ramesh, Studying Public Policy, Oxford University Press, Oxford, UK, 1995.

[25] D. Jacobs, "Innovation policies within the framework of internationalization," Research Policy, vol. 27, no. 7, pp. 711-724, 1998.

[26] A. M. McGahan, How Industries Evolve, Harvard Business Press, Boston, Mass, USA, 2004.

[27] G. A. Moore, Dealing with Darwin: How Great Companies Innovate at Every Phase of Their Evolution, Penguin, New York, NY, USA, 2006.

[28] T. L. Saaty, The Analytic Hierarchy Process, McGraw-Hill, New York, NY, USA, 1980.

[29] T. L. Saaty, Decision Making for Leaders, Lifetime Learning Publications, Belmont, Calif, USA, 1985.

[30] T. L. Saaty, "How to make a decision: the analytic hierarchy process," European Journal of Operational Research, vol. 48, no. 1, pp. 9-26, 1990.

[31] T. L. Saaty and K. P. Kearns, Analytical Planning: The Organization of Systems, vol. 4 of The Analytic Hierarchy Process Series, RWS Publications, Pittsburgh, Pa, USA, 1991.

[32] Y.-J. Lai, T.-Y. Liu, and C.-L. Hwang, “TOPSIS for MODM," European Journal of Operational Research, vol. 76, no. 3, pp. 486-500, 1994.

[33] S. J. Chen and C. L. Hwang, Fuzzy Multiple Attribute Decision Making: Methods and Applications, Springer, Berlin, Germany, 1992.

[34] C. L. Hwang and K. Yoon, Multiple Attribute Decision Making, Lecture Notes in Economics and Mathematical Systems, Springer, Berlin, Germany, 1981.

[35] S. Opricovic and G.-H. Tzeng, "Compromise solution by MCDM methods: a comparative analysis of VIKOR and TOPSIS," European Journal of Operational Research, vol. 156, no. 2, pp. 445-455, 2004.

[36] A. Smith, An Inquiry into the Nation and Causes of the Wealth of Nations, vol. 4, Clarendon Press, Oxford, UK, 1869.

[37] J. A. Schumpeter, The Theory of Economic Development, Harvard University Press, Cambridge, Mass, USA, 1934.

[38] M. E. Porter, "Competitive strategy in emerging industries," in Competitive Strategy: Techniques for Analyzing Industries and Competitors, pp. 215-236, Free Press, New York, NY, USA, 1980.

[39] R. Rothwell and W. Zegveld, Industrial Innovation and Public Policy: Preparing for the 1980s and the 1990s, Frances Pinter Publishers, 1981.

[40] H.-C. Chen and C.-H. Yang, "The cross-strait co-opetitive strategy analysis in wafer-base solar cell industry-national competitiveness perspective," in Proceedings of the IEEE International Summer Conference of Asia Pacific Business Innovation and Technology Management (APBITM '11), pp. 95-98, Beijing, China, July 2011.

[41] SEIA, “U.S. solar market insight Q12013," Research Report, 2013.

[42] IBIS World, Solar Panel Manufacturing in China Industry Research Report, 2013. 
[43] PIDA, 2013 Solar Cell Market and Industry Development, 2013 (Chinese).

[44] M. G. Wang and F. Ding, 2012 Environment Analysis in Solar Industry, IEK-IT IS, 2012 (Chinese).

[45] C. Hill and G. R. Jones, Strategic Management-Theory: An Integrated Approach, South-Western Cengage Learning, Mason, Ohio, USA, 2010.

[46] C.-H. Yang and J. Z. Shyu, "Cross-national and cross-industrial comparison of two strategy approaches for global industrial evolution," Technological Forecasting and Social Change, vol. 76, no. 1, pp. 2-25, 2009.

[47] Y.-H. Chu, "Taiwan's national identity politics and the prospect of cross-strait relations," Asian Survey, vol. 44, no. 4, pp. 484512,2004

[48] K. M. Sutter, "Business dynamism across the Taiwan Strait: the implications for cross-strait relations," Asian Survey, vol. 42, no. 3, pp. 522-540, 2002.

[49] C.-Y. Tung, "Cross-strait economic relations: China's leverage and Taiwan's vulnerability," Issues and Studies, vol. 39, no. 3, pp. 137-175, 2003.

[50] S.-H. Chen, “Taiwanese IT firms' offshore R\&D in China and the connection with the global innovation network," Research Policy, vol. 33, no. 2, pp. 337-349, 2004. 


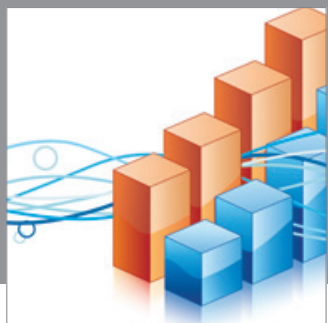

Advances in

Operations Research

mansans

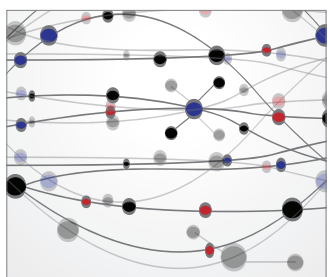

The Scientific World Journal
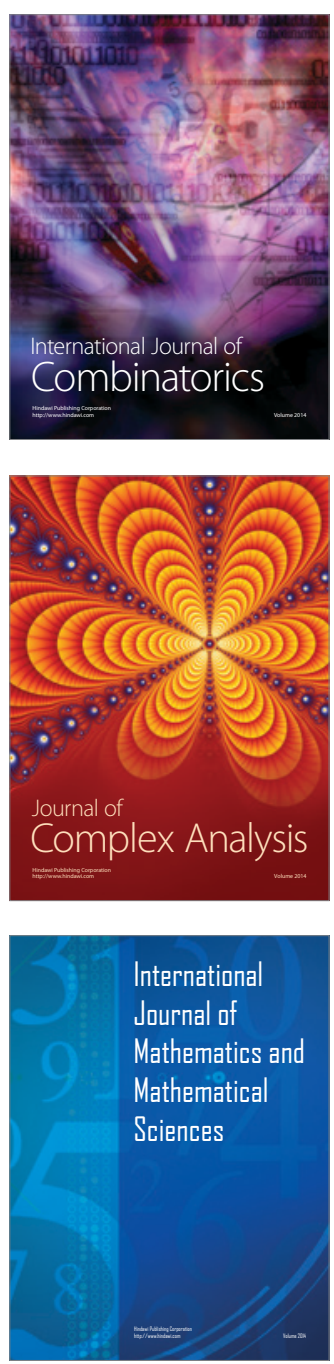
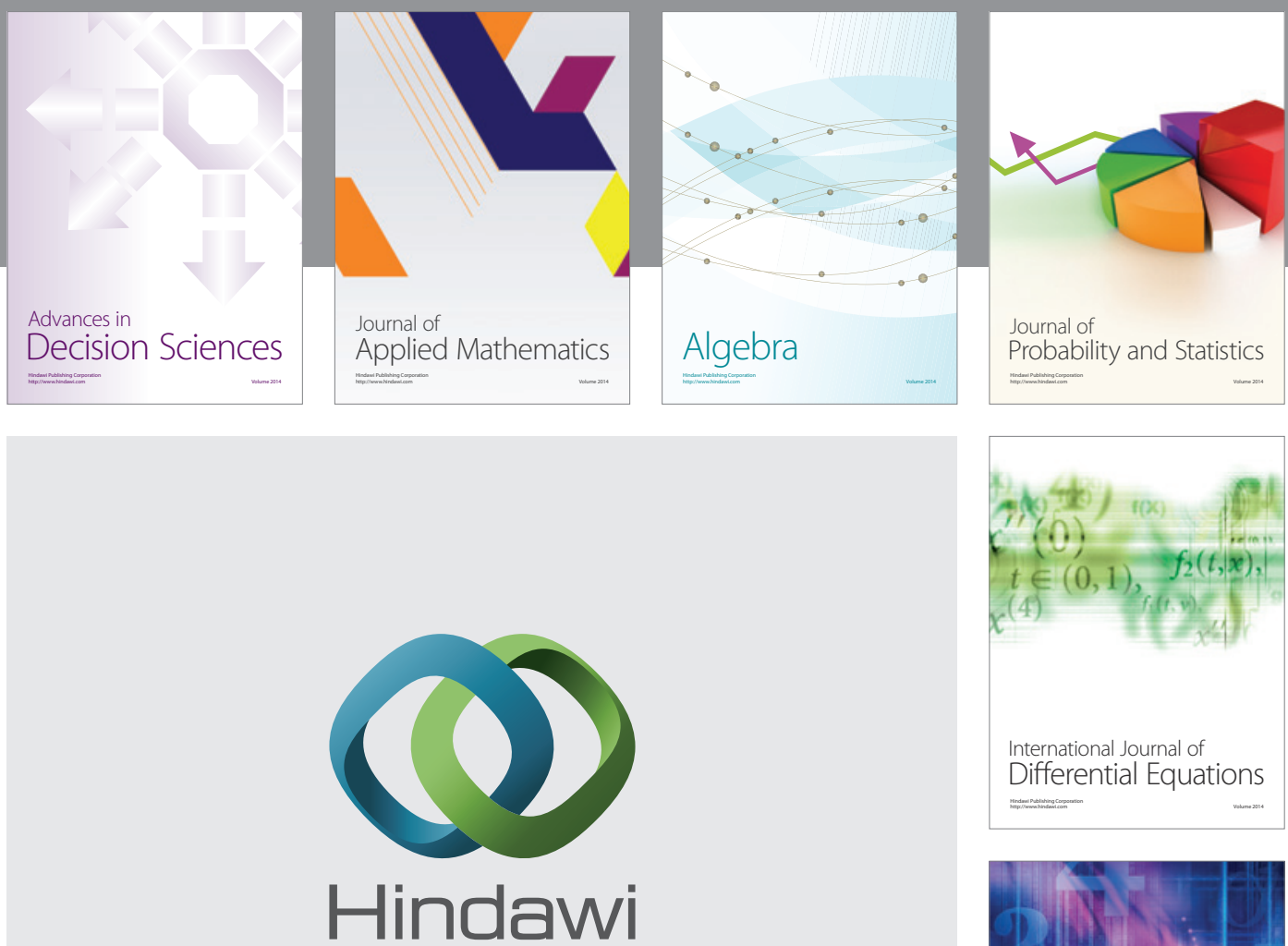

Submit your manuscripts at http://www.hindawi.com
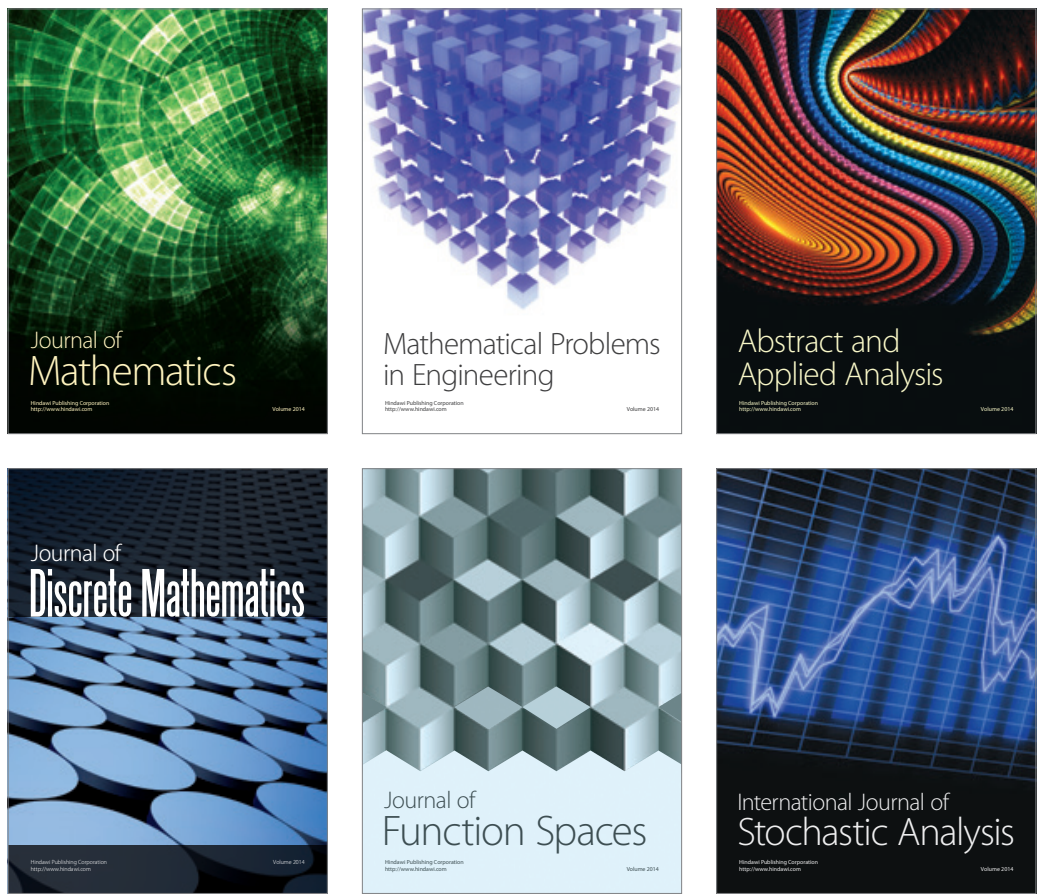

Journal of

Function Spaces

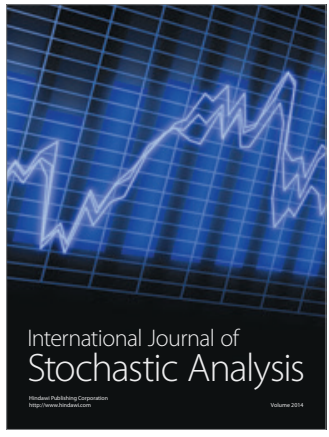

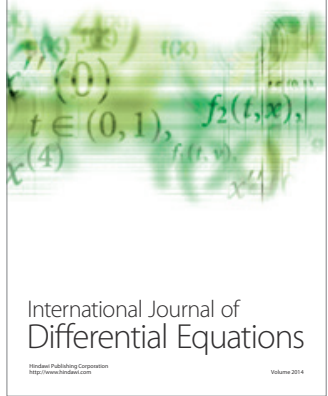
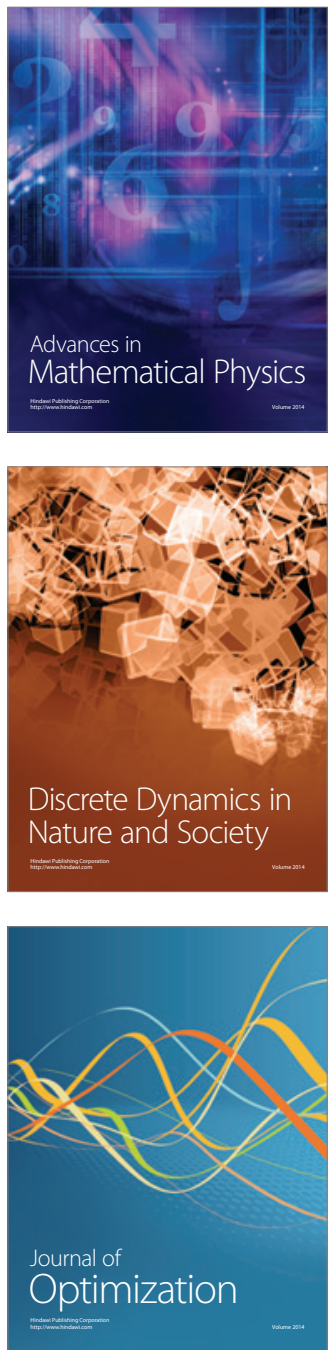